\title{
Arbuscular Mycorrhizal Fungi and Glomalin
}

\author{
Aydın Atakan ${ }^{1, a, *}$ Hülya Özgönen Özkaya ${ }^{2, b}$ \\ ${ }^{1}$ Department of Plant and Animal Production, Araban Vocational School, Gaziantep University, 27840 Gaziantep, Turkey \\ ${ }^{2}$ Department of Plant Protection, Faculty of Agriculture, Isparta University of Applied Sciences, 32100 Isparta, Turkey \\ *Corresponding author
}

\begin{tabular}{l|l}
\hline A R T I C E I N F O & A B S T R A C T \\
\hline Review Article & $\begin{array}{l}\text { The interactions between plant, soil, and mycorrhizal fungi are ecologically and agriculturally } \\
\text { beneficial systems. Mycorrhizal fungi are capable of forming a symbiosis with the roots of many } \\
\text { plants in nature. In this symbiosis, the plant receives help from the mycorrhizal fungus in nutrient and } \\
\text { water uptake. On the other hand, the mycorrhizal fungi supply the assimilant products they need from } \\
\text { the plant. In addition to the many benefits of AMF, they have very important roles in carbon (C) } \\
\text { storage in the soil. These roles of AMF are associated with the production of a substance named } \\
\text { "Glomalin". Glomalin, an N-linked glycoprotein that is considered to be AMF gene products, is } \\
\text { Accepted : } 17 / 11 / 2021 \\
\text { defined as a protein secreted by AMF hyphae and spores. Glomalin significantly reduces the } \\
\text { degradation of soil organic matter by preserving unstable compounds in soil aggregates. Glomalin, } \\
\text { which helps soil aggregation, is also an excellent hyphae protector. }\end{array}$
\end{tabular}

Arbuscular mycorrhizal fungi

Glomalin

Symbiosis

Soil organic matter

Potential toxic element

Türk Tarım - Gıda Bilim ve Teknoloji Dergisi, 9(12): 2371-2375, 2021

\section{Arbüsküler Mikorizal Funguslar ve Glomalin}

\begin{tabular}{l|l}
\hline M A K A L E B İ L G İ S İ & Ö Z \\
\hline $\begin{array}{l}\text { Derleme Makale } \\
\qquad: \text { 05/07/2021 }\end{array}$ & $\begin{array}{l}\text { Bitki, toprak ve mikorizal fungus üçgeni ekolôjik açıdan değerlendirildiğinde oldukça yararlı bir } \\
\text { sistemdir. Mikorizal funguslar doğadaki pek çok bitkinin kökleriyle ortak yaşama sahip funguslardır. } \\
\text { Bu simbiyotik yaşamda, bitki mikorizal fungustan besin elementi ve su alımı konusunda yardım } \\
\text { almakta, mikorizal fungus ise beslenmebilmek için bitkiden karbon kaynağ1 almaktadır. AMF birçok } \\
\text { faydasının yanı sıra toprakta karbon (C) depolamasında çok önemli rolleri vardır. AMF'nin bu rolleri, } \\
\text { "Glomalin" adlı bir maddenin üretimi ile ilişkilidir. AMF gen ürünleri olarak kabul edilen N-bağlı bir } \\
\text { Geliş }\end{array}$ \\
$\begin{array}{l}\text { Anahtar Kelimeler: } \\
\text { Arbüsküler mikorizal funguslar } \\
\text { Glomalin }\end{array}$ & $\begin{array}{l}\text { Glomalin, toprak agregalarında kararsız bileşikleri koruyarak toprak organik maddesinin bozulmasını } \\
\text { onemli ölçüde azaltır. Toprak agregasyonuna yardımcı olan glomalin aynı zamanda mükemmel bir } \\
\text { hif koruyucudur. }\end{array}$
\end{tabular}

Simbiyotik yaşam

Toprak organik maddesi

Potansiyel toksik element 


\section{Introduction}

Agricultural systems based on the intensive use of pesticides and inorganic fertilizers to compensate the nutritional needs of humanity emerged a long time ago. However, high input use brings with it serious problems such as the deterioration of agricultural ecosystems and the emergence of high environmental costs. These disadvantages have led to increased demands to reorganize agricultural practices to make agricultural systems more sustainable (Lee and Eom, 2009). Arbuscular Mycorrhizal Fungi (AMF) are very important for plant physiology, plant health, nutrient cycling and soil aggregation, especially for low-input sustainable agricultural systems (Bethlenfalvay and Barea, 1994).

AMF, classified in the division Glomeromycota, are obligate symbionts that form a symbiotic associations with more than $80 \%$ of terrestrial plant families. (Smith and Read, 2008). This relationship between plants and AMF, which connects the root and soil system, has been described by Koide and Mosse (2004) as one of the most important symbiosis on earth.

AMF directly mediates the uptake of phosphorus $(\mathrm{P})$, one of the essential nutrients required for plant growth, by colonizing plant roots. AM formations such as extraradical mycelium and filamentous hyphae networks that rapidly develop around plant roots increase the uptake efficiency of immobile phosphorus ions. (Sanders and Tinker, 1971; Grant et al., 2005; Smith and Read, 2008). In this respect, AMF causes hydrolysis of organic phosphate present in the soil through hyphae and providing soluble phosphate to its hosts. (Bagyaraj et al., 2015).

The effective roles of mycorrhizal fungi in increasing phosphorus uptake have been explained by some mechanisms by different researchers. These mechanisms are listed as follows: (I) AMF makes the inorganic phosphates with very low solubility useful by secreting some enzymes and acidic liquids that lower the $\mathrm{pH}$ in the immediate vicinity of the plant roots. (Hayman and Mosse, 1972), (II) These fungi take in the organic phosphorus compounds that are not suitable for the plant in the soil as their own nutrient requirement and then make these phosphorus compounds available within the hyphae cell and carry them to the plant roots (Hayman, 1982), (III) AMF hyphae create a continuous absorbing surface like a sponge layer on the surface of the plant roots, collect the phosphorus compounds that they have previously converted to suitable with various activities in the soil, on the root surface with the help of this absorbing surface and carry them to the plant root with the help of hyphae. (Bolan, 1991). While AM fungal colonization is inhibited at excessive phosphorus concentration, it is quite high in limited situations. AMF increases crop productivity by increasing nutrient uptake in soils with the low phosphorus content. (Grant et al., 2005).

In addition to increasing phosphorus uptake, AMF aids the host plant's uptake of mineral nitrate, potassium, and other forms of nutrients. Also, they have played an important role in increasing heavy metal and salt tolerance, increasing resistance to drought, improving resistance to pests and protecting plants against soil-borne pathogens. (Auge et al., 1994; Gange and West, 1994; Khan et al., 2000; Feng et al., 2002; Smith and Read, 2008; Atakan et al., 2018; Atakan and Ozgonen Ozkaya., 2021). Apart from these, AMF can interact with beneficial microorganisms such as phosphate-solubilizing bacteria (Toro et al., 1998) and Trichoderma spp. which have beneficial effects on nutrient cycling and plant nutrition (Singh et al., 2010).

AMF exist in two different phases in soil and inside plant roots. The intraradical mycelium belonging to these fungi consists of structures such as arbuscules, which provide nutrient and carbon exchange between symbionts, and vesicle, which is the lipid storage of fungi. The extraradical mycelium is responsible for the discovery of new areas for spore formation, nutrient uptake and colonization (Rillig, 2004).

In addition to the above benefits, AMF have very important role in carbon (C) storage in the soil (Zhu and Miller, 2003; Rillig and Mummey, 2006). These roles of AMF are associated with the production of a substance named glomalin. Glomalin, an N-linked glycoprotein (Schindler et al., 2007), which is considered to be AMF gene product, is defined as a protein secreted by AMF hyphae and spores. It is measured from the soil as Glomalin-Related Soil Protein (GRSP) (Wright and Upadhyaya 1996; Rillig 2004; Singh et al., 2013).

Among soil biota, AMF are critical for soil aggregation and can alleviate plant stress. (Lehmann and Rillig, 2015; Ortiz et al., 2015). Glomalin, an important component of soil organic matter and putative gene product of arbuscular mycorrhizal fungi, contributes to better aggregate formation. (Wright and Upadhyaya, 1998). Glomalin is of great importance in determining numerous aspects of soil quality, including soil organic matter, nutrient storage capacity, and water holding capacity. Therefore, AMF are not only a factor but also a key determinant of soil quality. (Paul and Clark, 1989).

In this review, it was aimed to give some information about mycorrhizal fungi and glomalin, which is supposed to be the gene products of these fungi.

\section{Discovery of Glomalin and Definition}

Glomalin was firstly described in 1996 as a glycoprotein secreted from AMF spores and hyphae. Since this protein is secreted by the genera Acaulospora, Entrophospora, Gigaspora, Glomus and Scutellospora belonging to the order Glomales, it is expressed with the name "Glomalin". (Wright et al., 1996). Monoclonal antibodies (MAb32B11) produced against spores of Glomus intraradices FL208 were used to detect the presence of glomalin. As a result of studies on in vitro cultures of Rhizophagus intraradices (N.C. Schenck \& G.S. Sm.) C. Walker \& A. Schüßler, it has been reported that glomalin is tightly bound to hyphae and spore walls. It has also been reported that about $80 \%$ of this protein is secreted by the hyphae and spores of AMF. (Driver et al., 2005).

Glomalin, which cannot be produced by fungi other than Glomeromycota, is a stable compound that is insoluble in water and resistant to heat degradation. (Wright et al., 1996). Glomalin can be found in agricultural soils, grasslands, forest soils, desert and uncultivated soils (Wright and Upadhyaya 1996; Rillig et al., 2003; Antibus 
et al., 2006; Bai et al., 2009). Positive results have been obtained from the studies conducted to prove that glomalin is of AMF origin. In a study conducted by Steinberg and Rillig (2003), they concluded that when the development of AMF was eliminated, there was a decrease in glomalin concentration.

Glomalin is not only a component within the walls of AMF hyphae and spores, but may also exist on the surface of extraradical mycelium. By decomposition of the hyphae, glomalin penetrates into the soil and is called GlomalinRelated Soil Protein (GRSP) (Rillig, 2004; Driver et al., 2005).

Host plant species, photosynthesis and productivity, soil management and soil physicochemical properties are the factors affecting GRSP production (Treseder and Turner 2007; Violi et al., 2007; Wang et al., 2011; Wu et al., 2013). The rate of glomalin production is not always proportional to the abundance of AMF in the soil. Therefore, the permanent stocks of hyphae, the glomalin content of the hyphae, and the hyphae turnover rate determine the rate of accumulation of glomalin in the soil. Permanent glomalin stocks in the soil are determined by the production and decomposition of glomalin, and ecological conditions can affect the two situations independently (Rillig, 2004).

\section{Content of Glomalin and Classification}

Glomalin is a hydrophobic protein. It contains iron (2$5 \%$ ), oxygen $(4-6 \%)$, phosphorus $(0.03-0.1 \%)$, carbon (36-59\%), hydrogen (33-49\%) and nitrogen (3-5\%). (Wright et al., 1998; Lovelock et al., 2004). The reddishbrown appearance of glomalin extracts is due to the iron content (Wright and Upadhyaya, 1998; Rillig et al., 2001). It was reported that glomalin is present in soils in concentrations that are up to four times as great as humic acid concentrations, it is persistent, and it is generally associated with the insoluble humus or mineral fractions after treating soils with sodium hydroxide (Comis, 2002).

In general, GRSP is classified as easily extractable glomalin-associated soil protein (EE-GRSP) and total glomalin-associated soil protein (T-GRSP). There is a problem of terminological confusion about the specific protein glomalin. Therefore, there are four positively correlated variables used to describe the glomalin extracted from the soil. These; It is defined as EEBRSP (easily extractable BRSP), BRSP (Bradford reactive soil protein), IRSP (immuno reactive MAb32B11 soil protein) EE-IRSP (easily extractable immune reactive MAb32B11 soil protein). An important aspect of this new terminology is that glomalin in the strict sense is expressed only as the gene product generated by AMF. However, evidence of AMF origin of GRSP is highest for monoclonal antibody immune reactive fractions (Wright and Upadhyaya, 1996; Rillig et al., 2004; Singh, 2012).

\section{Agricultural Importance of Glomalin}

There is a strong relationship between glomalin concentration and soil aggregate stability (Wright and Upadhyaya, 1998; Wright and Anderson, 2000). Because of this role, glomalin significantly reduces the degradation of soil organic matter by preserving unstable compounds in soil aggregates (Rillig, 2004). Glomalin, which helps soil aggregation, is also an excellent hyphae protector. Due to its high stickiness and hydrophobicity, it contributes significantly to the stabilization of soil particles. Apart from this, it represents a stable form of organic C stores, which represent a significant part of soil organic matter (Rillig et al., 2003). Soil aggregate stability positively associated with GRSP is more pronounced under drought stress. GRSP plays an important role in preventing the loss of water and nutrients from plants exposed to abiotic stress by providing the formation of a hydrophobic layer on the aggregate surface (Nichols, 2008; Wu et al., 2008). Because decomposition and death of mycorrhizal hyphae are promoted under drought stress, more GRSP is secreted in soils (Driver et al., 2005). This situation indicates both the phytopathological importance of AMF-plant interaction and the importance of interaction between symbionts under stress conditions. In this way, the preservation of water and nutrients necessary for plants is increased, and beneficial effects are provided on plant development.

Glomalin also has an important role in the formation of microbial communities in soil. Chemical fertilizers affect glomalin production as they affect the symbiotic relationships of AMF. In a study in which different nitrogen $(0,2,6,10 \mathrm{mM})$ levels were applied to alfalfa (Trifolium repense L.), plants inoculated Rhizophagus irregularis (Błaszk., Wubet, Renker \& Buscot) C. Walker \& A. Schüßler and Rhizobium leguminosarum pv. trifolii. In this study, it was reported that significant increases in glomalin production were observed with the interaction between Rhizophagus irregularis and Rhizobium leguminosarum. In addition, the percentage of root colonization increased compared to the control, depending on the increasing nitrogen levels. Since the main component of glomalin is nitrogen, the assimilant products obtained as a result of photosynthesis are transmitted to AMF via roots and used for glomalin synthesis in AMF spores and hyphae walls. After the plant assimilants are transferred to AMF, they can be converted to nitrogenous compounds if sufficient nitrogen sources are available. Accordingly, a significant amount of carbon is assimilated into AMF and soil particles (Zenoozagh, 2018). It can be concluded that carbon sequestration with this symbiotic relationship in terrestrial ecosystems can be improved by applying nitrogen fertilization at the optimum level.

The rhizosphere contains many microorganisms. It can both promote and inhibit plant growth and development through interactions between organisms. (Barea et al., 2005). The interactions between PGPR and AMF are very important because of their contribution to the productivity and sustainability of agricultural and natural ecosystems (Requena et al., 1997; Walley and Germida, 1997; Adesemoye et al., 2008). Several studies have reported that using PGPR promotes the beneficial role of AMF (Hodge, 2000; Barea et al., 2002; Barea et al., 2005).

Some PGPR produce phytohormones that increase AMF colonization by increasing root surface area and plant susceptibility to AMF penetration. (Barea et al., 2002; Dwivedi et al., 2009). For this reason, this PGPR is defined as "mycorrhization-helper bacteria" (Garbaye, 1994). AMF affect the bacterial population in the root zone and provide the accumulation of photosynthesis products in the 
mycorrhizosphere (Hodge, 2000). As a result of increasing mycorrhizal colonization by PGPR, glomalin production increases (Purin and Rillig, 2007).

Another important point in terms of plant health is the presence of toxic metals such as $\mathrm{Cu}, \mathrm{Cd}, \mathrm{Zn}$ and $\mathrm{Pb}$ in the soil. It has been suggested that the most appropriate use for these elements is potentially toxic elements (PTEs) (Gadd, 1993; Alloway, 1995). AM Fungi are capable of absorbing $\mathrm{Cu}$, and $1 \mathrm{~g}$ of AMF hyphae has a $\mathrm{Cu}$ content of 3-14 mg (Gonzalez-Chavez et al., 2002). Glomalin, gene products of AMF, are effective with mechanisms such as stabilizing PTE, optimizing the presence of PTE in the soil and reducing the risk of toxicity for other soil microorganisms and plant roots in the rhizosphere. These properties reflect another beneficial aspect of glomalin in addition to its other roles.

\section{Conclusion}

The promotion of mycorrhizal symbiosis has great potential to benefit modern agricultural systems. Recently, increasing interest in environmental protection and ecofriendly agricultural practices are among the potential important issues by minimizing the use of mineral fertilizers and synthetic chemicals. Unlike conventional agricultural practices, mycorrhizal fungi, which is a trend approach, protect their hosts against plant pathogens by various mechanisms. AMF, which is important as an effective bio-fertilizer and bio-preservative in sustainable agriculture, is also among the most necessary factors of the modern agricultural age by interacting with other microorganisms. In addition to its other important features, the glomalin secreted by AM fungi improves the soil structure and provides optimum conditions for plant growth. In addition, the ability of AM Fungi to retain and accumulate PTEs in a non-toxic form, the benefits of improving plant health and soil quality in polluted areas can be considered as the only components of modern agriculture. It is thought that some problems brought by conventional practices can be eliminated or alleviated by giving the necessary importance to the widespread use of these symbionts, which are very beneficial to the agroecosystem. For this reason, there is a need for detailed studies on the subject.

\section{References}

Adesemoye AO, Torbert HA, Kloepper JW. 2008. Enhanced plant nutrient use efficiency with PGPR and AMF in an integrated nutrient management system. Canadian Journal of Microbiology, 54: 876-886.

Alloway BJ. 1995. Heavy Metals in the Soil. Chapman and Hall, London.

Antibus RK, Lauber C, Sinsabaugh RL, Zak DR. 2006. Responses of Bradford-reactive soil protein to experimental nitrogen addition in three forest communities in northern lower Michigan. Plant and Soil, 288: 173-187.

Atakan A, Özgönen Özkaya H, Erdoğan O. 2018. Effects of arbuscular mycorrhizal fungi (AMF) on heavy metal and salt stress. Turkish Journal of Agriculture - Food Science and Technology, 6(11): 1569-1574.

Atakan A, Özgönen Özkaya H. 2021. Induced resistance to Fusarium wilt in carnation with mixture of mycorrhizal fungi. Fresenius Environmental Bulletin, 30(04A): 4217-4227.
Auge RM, Duan XG, Ebel RC, Stodola AJ. 1994. Nonhydraulic signalling of soil drying in mycorrhizal maize. Planta, 193: 74-82.

Bagyaraj DJ, Sharma MP, Maiti D. 2015. Phosphorus nutrition of crops through arbuscular mycorrhizal fungi. Current Sciences, 108(7): 1288-1293.

Bai C, He X, Tang H, Shan B, Zhao L. 2009. Spatial distribution of arbuscular mycorrhizal fungi, glomalin and soil enzymes under the canopy of Astragalus adsurgens Pall. inthe Mu Us sandland, China. Soil Biology and Biochemistry, 41: 941947.

Barea JM, Azcon R, Azcon-Aguilar C. 2002. Mycorrhizosphere interactions to improve plant fitness and soil quality. Journal of Microbiology, 81: 343-351.

Barea JM, Pozo M, Azcon, R, Azcon-Aguilar C. 2005. Microbial cooperation in the rhizosphere. Journal of Experimental Botany, 56: 1761-1778.

Bethlenfalvay GJ, Barea JM. 1994. Mycorrhizae in sustainable agriculture. I. Effects on seed yield and soil aggregation. American Journal of Alternative Agriculture, 9: 157-161.

Bolan NS. 1991. A Critical Review on the Role Mycorrhizal Fungi in the Uptake of Phosphorus by Plants. Plant and Soil, 134: 189-207.

Comis D. 2002. Glomalin: a hiding place for a third of the world's stored soil carbon. Agricultural Research, p. 4.

Driver JD, Holbenand WE, Rillig MC. 2005. Characterization of glomalin as a hyphal Wall component of arbuscular mycorrhizal fungi. Soil Biology and Biochemistry, 37: 101106.

Dwivedi D, Johri BN, Ineichen K, Wray V, Wiemken A. 2009. Impact of antifungals producing rhizobacteria on the performance of Vigna radiata in the presence of arbuscular mycorrhizal fungi. Mycorrhiza, 19: 559-570.

Feng G, Zhang FS, Li XL, Tian CY, Tang C, Rengel Z. 2002. Improved tolerance of maize plants to salt stress by arbuscular mycorrhiza is related to higher accumulation of soluble sugars in roots. Mycorrhiza, 12: 185-190.

Gadd GM. 1993. Interaction of fungi with toxic metals. New Phytologist, 124: 25-60.

Gange AC, West HM. 1994. Interactions between arbuscular mycorrhizal fungi and foliar-feeding insects in Plantago lanceolata L. New Phytologist, 128: 79-87.

Garbaye J. 1994. Helper bacteria: a new dimension to the mycorrhizal symbiosis. New Phytologist, 128: 197-210.

Gonzalez-Chavez C, Haen J, Vangronsveld J, Dodd JC. 2002. Copper sorption and accumulation by the extraradical mycelium of different Glomus spp. (arbuscular mycorrhizal fungi) isolated from the same polluted soil. Plant and Soil, 240: 287-297.

Grant C, Bittman S, Montreal M, Plenchette C, Morel C. 2005. Soil and fertilizer phosphorus: effects on plant P supply and mycorrhizal development. Canadian Journal of Plant Science, 85: 3-14.

Hayman D, Mosse B. 1972. Plant Growth to Vesicular Arbuscular Mycorrhiza. III Increased Uptake of Labille P from Soil. New Phytologist, 71: 41-47.

Hayman, D. 1982. Influence of Soils and Fertility on Activity and Survial Vesicular - Arbuscular Mycorrhizal Fungi. Phytopathology, 72: 1119-1126.

Hodge A. 2000. Microbial ecology of the arbuscular mycorrhizal. Microbiology and Ecology, 32: 91-96.

Khan AG, Kuek C, Chaudhry TM, Khoo CS, Hayes WJ. 2000. Role of plants, mycorrhizae and phytochelators in heavy metal contaminated land remediation. Chemosphere, 41: 197207.

Koide RT, Mosse B. 2004. A history of research on arbuscular mycorrhiza. Mycorrhiza, 14: 145-163.

Lee JE, Eom AH. 2009. Effect of Organic Farming on Spore Diversity of Arbuscular Mycorrhizal Fungi and Glomalin in Soil. Mycobiology, 37(4): 272-276. 
Lehmann A, Rillig MC. 2015. Understanding mechanisms of soil biota involvement in soil aggregation: a way forward with saprobic fungi? Soil Biology and Biochemistry, 88: 298-302.

Lovelock CE, Wright SF, Clark DA, Ruess RW. 2004. Soil stocks of glomalin produced by arbuscular mycorrhizal fungi across a tropical rain forest land scape. Journal of Ecology, 92: 278287.

Nichols KA. 2008. Indirect contributions of AM fungi and soil aggregation to plant growth and protection. Sustainable Agriculture and Forestry, 177-194.

Ortiz N, Armada E, Duque E, Roldan A, Azcon R. 2015. Contribution of arbuscular mycorrhizal fungi and/or bacteria to enhancing plant drought tolerance under natural soilc onditions: effectiveness of auto chthonous strains. Journal of Plant Physiology, 174: 87-96.

Paul EA, Clark FE. 1989. Soil biology and biochemistry. Academic Press, San Diego, CA

Purin S, Rillig MC. 2007. The arbuscular mycorrhizal fungal protein glomalin: Limitations, progress, and a new hypothesis for its function. Pedobiologia, 51: 123-130.

Requena N, Jimenez I, Toro M, Barea JM. 1997. Interactions between plant-growth-promoting rhizobacteria (PGPR), arbuscular mycorrhizal fungi and Rhizobium spp. in the rhizosphere of Anthyllis cytisoides, a model legume for re vegetation in mediterranean semi-arid ecosystems. New Phytologist, 136: 667-677.

Rillig MC, Mummey DL. 2006. Mycorrhizas and soil structure. New Phytologist, 171: 41-53.

Rillig MC, Ramsey PW, Morris S, Paul EA. 2003. Glomalin, an arbuscular-mycorrhizal fungal soil protein, responds to landuse change. Plant and Soil, 253: 293-299.

Rillig MC. 2004. Arbuscular mycorrhizae and terrestrial ecosystem processes. Ecological Letter, 740-754.

Rillig MC. 2004. Arbuscular mycorrhizae, glomalin, and soil aggregation. Canadian Journal of Soil Science, 84: 355-363.

Rillig MC. Wright SF, Nichols KA, Schmidt WF, Torn MS. 2001. Large contribution of arbuscular mycorrhizal fungi to soil carbon pools in tropical forest soils. Plant and Soil, 233: 167177.

Sanders FE, Tinker PB. 1971. Mechanism of absorption of phosphate from soil by Endogonemycorrhizas. Nature, 233278.

Schindler FV, Mercer ER, Rice JA. 2007. Chemical characteristics of glomalin-related soil protein (GRSP) extracted from soils of varying organic matter content. Soil Biolohgy and Biochemistry, 39: 320-329.

Singh PK, Singh M, Tripathi BN. 2013. Glomalin: an arbuscular mycorrhizal fungal soil protein. Protoplasma, 250: 663-669.

Singh PK. 2012. Role of Glomalin Related Soil Protein Produced by Arbuscular Mycorrhizal Fungi. A Review. Agricultural Science Research Journal. 2(3): 119-125.

Singh VPN, Singh RL, Yadav SK, Awasthi BB, Joshi RK, Singh RJ, Lal, Duttamajumder SK. 2010. Increasing the efficacy of Trichoderma harzianum for nutrient uptake and control of red rot in sugarcane. Journal of Horticulture and Forestry, 2(4): 66-71.

Smith SE, Read DJ. 2008. Mycorrhizal Symbiosis. 3rd edition. Academic Press, San Diego.
Steinberg PD, Rillig MC. 2003. Differential decomposition of arbuscular mycorrhizal fungal hyphae and glomalin. Soil Biology and Biochemistry, 35: 191-194.

Toro M, Azcon R, Barea JM. 1998. The use of isotopic dilution techniques to evaluate the interactive effects of Rhizobium genotype, mycorrhizal fungi, phosphate-solubilizing rhizobacteria and rock phosphate on nitrogen and phosphorus acquisition by Medicago sativa. New Phytologist, 138: 265273.

Treseder KK, Allen F. 2000. Mycorrhizal fungi have a potential role in soil carbon storage under elevated $\mathrm{CO} 2$ and nitrogen deposition. New Phytologist, 147: 189-200.

Treseder KK, Turner KM. 2007. Glomalin in ecosystems. Soil Science, 71: 1257-1266.

Violi HA, Treseder KK, Wright SF, Lovatt CJ. 2007. Density dependence and interspecific interactions between arbuscular mycorrhizal fungi mediated plant growth, glomalin production, and sporulation. Canadian Journal of Botany, 85: 63-75.

Walley FL, Germida JJ.(1997. Response of spring wheat (Triticum aestivum) to interactions between Pseudomonas species and Glomus clarum NT4. Biology and Fertility of Soils, 24: 365-371.

Wang P, Liu JH, Xia RX, Wu QS, Wang MY, Dong T. 2011. Arbuscular mycorrhizal development, glomalin-related soil protein (GRSP) content, and rhizospheric phosphatase activity in citrus orchards under different types of soil management. Journal of Plant Nutrient Soil Science, 174: 6572.

Wright SF, Anderson RL. 2000. Aggregate stability andg lomalin in alternative crop rotations for the central Great Plains. Biology and Fertility of Soils, 31: 249-253.

Wright SF, Upadhyaya A, Buyer JS. 1998. Comparison of Nlinked oligo saccharides of glomalin from arbuscular mycorrhizal fungi and soils by capillary electrophoresis. Soil Biology and Biochemistry, 30: 1853-1857.

Wright SF, Upadhyaya A. 1996. Extraction of an abundant and unusual protein from soil and comparison with hyphal protein of arbuscular mycorrhizal fungi. Soil Science, 161: 575-586.

Wright SF, Upadhyaya A. 1998. A survey of soils for aggregate stability and glomalin, a glycoprotein produced by hyphae of arbuscular mycorrhizal fungi. Plant and Soil, 198: 97-107.

Wu QS, He XH, Cao MQ, Zou YN, Wang S, Li Y. 2013. Relationships between glomalin-related soil protein in waterstable aggregate fractions and aggregate stability in citrus rhizosphere. International Journal of Agricultural and Biology, 115: 603-606.

Wu QS, Xiaand RX, Zou YN. 2008. Improved soil structure and citrus growth after inoculation with three arbuscular mycorrhizal fungi under drought stress. European Journal of Soil Biology, 44: 122-128.

Zenoozagh VS, Aliasgharzad N, Majidi J, Hajiboland R, Baradaran B, Aghebati-Maleki L. 2018. The effect of rhizobium on glomalin production by Rhizophagus irregularis in symbiosis with clover plant under different levels of nitrogen. Journal of Water and Soil, 32(2): 399-413.

Zhu Y, Miller RM. 2003. Carbon cycling by arbuscular mycorrhizal fungi in soil-plant systems. Trends Plant Science, 8: 407-409. 